\title{
Novelas and the development of a democratic culture in Brazil
}

\author{
Novelas e o desenvolvimento da cultura democrática no Brasil
}

\section{Daniel Zirker}

Ph.D, Professor of The University of Waikato, Hamilton, New Zealand

dzirker@waikato.ac.nz

\section{Paulo Gustavo Pellegrino Correa}

Ph.D, Professor of the Universidade Federal de Amapá (UNIFAP), Macapá, Amapá, Brazil

paulogustav01978@gmail.com

\begin{abstract}
Latin American novelas, or soap operas, have a unique, socially emancipatory character, and are popular world-wide. Despite their sponsorship by elite broadcast networks, they tend to focus upon the everyday struggles of the poor and lower middle class, for market reasons. One such Brazilian dramaturgy 'Você Decide', a popular television programme on the Brazilian national TV network Rede Globo between 1992 and 2000, offered viewers the chance, in a commercial break before the end of each instalment, to vote by telephone for one of the two possible endings. Coupled with the real moral and political dilemmas posed routinely on the serialized novelas, direct audience participation in Você Decide quickly became popular in Brazil, and its concept soon migrated abroad, where 'reality TV' programmes in the US, Europe, New Zealand and elsewhere continue to pay royalties to Rede Globo. It is contended that the social "emancipation" of Brazilian novelas, and the direct voting available in the dramaturgy Você Decide, and the "subliminal democracy" that these programs supported, where viewers participated in structuring a fictional setting laden with real world problems of direct relevance to them, ultimately conditioned the massive transformation of President Luiz Inácio (Lula) da Silva's voting base between 2002 and 2006, and may well explain some of the motivation behand the extensive social protests in Brazil in 2013.
\end{abstract}

Keywords: Novelas; "Você Decide"; Brazil; Emancipation; Democracy.

Resumo: Novelas latino-americanos têm um caráter social emancipatório único, e são populares em todo o mundo. Apesar de seu patrocínio ser feito por redes de transmissão de elite, elas tendem a se concentrar sobre as lutas cotidianas da classe baixa e media baixa, por razões de mercado. Entre as dramaturgias brasileiras, o 'Você Decide', um programa popular de televisão na rede nacional brasileira TV Rede Globo entre 1992 e 2000, ofereceu aos telespectadores a oportunidade nos intervalos comerciais antes do final do programa de votar por telefone para um dos dois finais possíveis. Juntamente com os dilemas morais e politicos reais passados diariamente nas novelas nacionais, a participação do público direto em Você Decide rapidamente se tornou popular no Brasil, e seu conceito logo migrou para o exterior, onde os programas de 'reality' nos EUA, Europa, Nova Zelândia passaram a pagar royalties para a Rede Globo. Argumenta-se que a "emancipação" social das novelas brasileiras, e o voto direto disponível no formato do programa 
Você Decide, e a "democracia subliminar" que esses programas apoiavam, onde os telespectadores participavam na estruturação de um cenário fictício carregado de problemas do mundo real de relevância direta para eles, em última análise, condicionaram a enorme transformação da base eleitoral do presidente Luiz Inácio (Lula) da Silva em 2002 e 2006, e pode muito ajudar a explicar parte da motivação por trás dos extensos protestos sociais no Brasil em 2013.

Palavras-chave: Novelas; "Você Decide”, Brasil; Emancipação; Democracia.

\section{Introduction}

How did Luís Inácio (Lula) da Silva, President of Brazil from 2003 to 2011, transform and galvanise his electoral base from a thin majority largely composed of disenchanted middle class in 2002 to a strong majority of largely poor and lower middle class by 2006? Why have many of those same voters engaged in violent protests against government policies in 2013? Lula's increased use of cash transfer payments through programmes such as Bolsa Familia, thought to have raised as many as 26 million people above the poverty line by 2006 (and voting for his second term), is usually cited as a central causal factor, although there is significant disagreement on this point. While we agree with the argument, perhaps best articulated by Timothy Powers of Oxford, that cash transfer payments were a significant causal variable, the receptivity and response of a newly enfranchised class to neo-populist (and neo-liberal) appeals, is by no means assured. Decades of machine voting, and visceral rejection of the power structure (including the act of voting itself), so basic to slum voters in particular, often take many decades to change. Hence, two further questions: why have Brazilian voters over the past decade demonstrated a patent disregard for traditional machine voting patterns (and sceptical "non-voting"), and why have they most recently protested events associated with national pride, the hosting of the World Cup (2014) and the Summer Olympics (2016)? Our principal hypothesis is the following: at least some of this effect, involving the key element of citizen receptivity to new patterns of participation, may be attributed to a kind of political education and 'emancipation' associated with Brazilian-style TV viewership, novelas and dramaturgies, which have intensified and instructed the democratic culture in Brazil, analogous to "conscientization" described by the late Brazilian educator and revolutionary, Paulo Freire (1996).
The novela, sometimes mistranslated as "soap opera,"1 has dominated Latin American and Brazilian TV for decades, and has established themes that are sensitive to the viewing market, e.g., poverty, violence, sexuality, race and corruption, in providing what some have called a kind of "emancipation" of the millions of impoverished and almost purely vicarious viewers in Brazil. Typically comprised of approximately 40 episodes, these TV dramaturgies explore difficult moral and personal problems likely to beset lower and lower middle class viewers, a majority of the TV viewing public, and the most effective advertising targets. Emancipation, in this sense, involves a focus topics that have rarely been in the interests of elite Brazilian culture, greater equality, justice, individual morality, making "wise" choices in morally tendentious situations, and so on. These widely viewed dramaturgies involve a systematic blurring of fact and fiction in what we have chosen to call "subliminal democracy." Moreover, the Brazilian novelas of the 1980s in effect prepared the TV viewing public, many of them poor, and a good percentage of those slum dwellers, for a pioneering TV dramaturgy that was not technically a novela, because each episode involved a new story and narrative, albeit in that same tradition. "Você Decide" (literally, "You Decide") invited weekly viewers to consider difficult moral and political questions, and then gave them the opportunity to 'vote' on a preferred outcome. It represented, in a large sense, an educational progression from the increasingly relevant novelas, one that stressed deliberative voting and the democratic conditioning of a previously manipulated and apathetic public.

It has been persuasively argued that the single greatest threat to democracy is the global proliferation of poverty. Some have attributed the expansion of poverty and urban slums, in particular, to the retreat

\footnotetext{
${ }^{1}$ Nico Vinc, in his important 1988 work, noted that "[...] despite their common origin, telenovelas are quite different from soap operas. They are truly Latin American. In the Brazilian case, they are locally made and are written by local authors about Brazilian themes [...]" (VINK 1988, p. 11).
} 
of the state in an age of neo-liberalism (e.g., DAVIS, 2006, p. 54; GOULD, 2006). The news in this regard is mostly pessimistic. Many countries, including Brazil, have had massive slum populations, and have developed over the past 50 years distinctive and violent slum cultures. According to a survey conducted in 2010 (IBGE, 2011) by the Brazilian Geographic and Statistics Institute (Instituto Brasileiro de Geografia e Estatística, or IBGE), Brazil had 11.42 million people living in favelas (slums), shacks or other sub-standard housing, in other words, 6 percent of the Brazilian population, and almost twice as many people since 1991. These figures substantially underestimate the total slum population, however. The two major Brazilian cities, São Paulo and Rio de Janeiro, have 43.7 percent of such agglomerations of substandard housing in Brazil, the favelas as they are called in Rio. This is a critical datum given that a major part of the television programs in Brazil are produced in, and therefore directed at the markets of, these two cities. In addition, there are vast stretches of the countryside that are dotted with small, impoverished towns, and now, most recently in Sao Paulo, the development of large rural slums, the equivalent of mid-sized towns of recent squatters without adequate services, comprised of ramshackle and unplanned housing located on the margins of huge export-oriented estates. They are often located near highways. Northeast Brazil, still the largest concentration of poverty in the Western Hemisphere, has a population of over 50 million people, and although it has increasingly been "colonised" with beach resorts for wealthy tourists, mostly from the south, it nevertheless evinces relatively poor health and literacy data, crumbling hospitals, and decaying schools. These conditions are said to be increasing in the wealthy center-eastern and southern regions as well. As millions of dollars are spent on sports facilities for the World Cup and Summer Olympics, protestors are for the first time making known their deliberate preference for national needs over national pride.

The following study explores one admittedly limited aspect of the complex relation between poverty and political culture, and between political culture and television viewing. The prevalence of lower and lower middle class TV viewers, and the eagerness with which otherwise ultra-conservative TV networks seek to be relevant to them, may offer a solution to the fundamental democratic conundrum, the involvement of poor and lower middle classes in voluntary, collective, and democratic behaviour, what Robert Putnam has referred to as "social capital". As Amelia Simpson noted in 1993 in her book on Xuxa, the stage name of the Brazilian TV personality and children's media phenomenon franchised in Brazil and throughout Latin America, the media in Brazil

[...] may be unique in the world today in its peculiar combination of a highly developed mass communications industry and an undereducated, needy population that nevertheless watches a lot of television [...] (SIMPSON, 1993, p. 2).

It is often remarked, moreover, that the age of electronic media has ultimately contributed to an age of global democratic behavior. Although early observers, notably political scientist Karl Deutsch, emphasized that " [...] communications engineering transfers information... it does not transfer events [...]" (DEUTSCH, 1963, p. 82, emphasis in the original), and that political power dynamics are only affected significantly if those receiving the message are in disequilibrium and especially receptive, Deutsch and his contemporaries had not yet seen the full significance of TV as a transformative influence in the developing world. As Deutsch put it in the 1960s, however,

[...] the effectiveness of information at the receiver depends on two classes of conditions. First of all, at least some parts of the receiving system must be in highly unstable equilibrium, so that the very small amount of energy carrying the signal will be sufficient to start off a much larger process of change. Without such disequilibrium already existing in the receiver, information would produce no significant effects. This obvious technical relationship might have some parallels in politics. The extent of the effect of the introduction of new information into a political or economic system might well be related, among other things, to the extent of the instabilities that already exist there [...] (DEUTSCH, 1963, p. 147).

He added that the "[...] second class of conditions involves the selectivity of the receiver [...]" (DEUTSCH, 1963, p. 148). For example, what if at least a small subgroup of those receiving the electronic message are feeling 'emancipated' by it, and are interacting with it, shaping it, and thereby actively constituting an event? Moreover, what if that relatively unimpressive act is expressing a real, if restrained, drive for political emancipation, in striving to make difficult ethical choices, and hence is beginning to practice the shaping of political patterns, and contributing, however insignificantly at first, directly, deliberately, and even wisely, to political outcomes? Deutsch argued that it is 'the "middle level" of communications and command', and a candidate's communication with this relatively small group in any political system, that ultimately has a decisive effect on political outcomes, not the individualised 'relationship' between the citizenry and a candidate (DEUTSCH, 1963, p. 154). 
The significance of such emancipation might have diverse ramifications. From a legal and philosophical standpoint, emancipation addresses the capacity of individuals to participate in civil society. It can also be regarded as a concept that explains the struggle against economic and symbolic oppression of a group of people who have been deprived of their rights and seek to obtain them through establishing their political equality. Such a struggle could be defined as emancipatory. In addressing the emancipation of groups we are working with a collective concept of identity (ethnicity, class, and gender) rather than one focused on individual actions. Collective action that brings about social change requires mass mobilization which usually stems from annoyance with a reality that comes to be seen as illegitimate and oppressive. Images and representations that identify this reality and make it possible to criticize it and even change it are precisely those elements that can initiate the process of mass mobilization and emancipation. As Paulo Freire put it,

As we attempt to analyse dialogue as a human phenomenon, we discover something which is the essence of dialogue itself: the word. But the word is more than just an instrument which makes dialogue possible; accordingly, we must seek its constitutive elements. Within the word we find two dimensions, reflection and action, in such radical interaction that if one is sacrificed - even in part - the other immediately suffers. There is no true word that is not at the same time a praxis. Thus, to speak a true word is to transform the world [...] (FREIRE, 1996, p. 87).

It is this connection between deliberation over the 'truth' and emancipation and mobilization that constitutes the unique role of television in Brazil. Although implemented for purely market/profit purposes, popular programming (the TV dramaturgies directed at the poor and lower middle classes) can be regarded not only as a potential route to individual emancipation in itself, but also as a means to creating conditions favourable to the mass mobilization of those pursuing a process of social and political emancipation. Nico Vink (1988, p. 130) noted that

Television is normally, in itself, not the cause of emancipation of the oppressed; this only can be realized by way of struggle after mobilizing a category on the basis of a common identity. Television is very important in the struggle for meaning and repression, especially in the construction of daily life common sense. Television can fortify the existing cultural domination by presenting inequality as normal or contribute, in special cases, to subversion by providing discourses which present it as oppressive and illegitimate, or offering possibilities for alternative reading.
The relevance of this observation is particularly apparent as regards 'Você Decide', the TV dramaturgy that appeared at a key historical juncture in Brazil, at the end of the military dictatorship (1964-1985), when the media in Brazil had recently been under the waning influence of authoritarian censorship. It perhaps should not be surprisingly that at this sensitive political moment TV programming broke with caution and adopted market-based themes, using them to advertise commercially to a growing, if largely impoverished, market. Given the prevailing demography of Brazilian TV viewers at the time, such social themes would likely have been censored by the previous authoritarian governments. In fact, had it not been for the ultra-conservative, politically influential, but profit-starved TV networks, and their insistence on appealing to the widest market, it is unlikely that the ethical and political relevance of the Brazilian TV dramaturgies would ever have emerged.

\section{Você Decide and reasoned choice}

In 1992, immediately following the first direct election of a president, and during his impeachment and removal by the Brazilian Congress, the Brazilian national TV network and corporate conglomerate, Rede Globo, the sponsor of the childrens' programming sensation, Xuxa, and the first Brazilian network to engage in market research and the evaluation of consumer trends (SIMPSON, 1993, p. 60), featured a subtly innovative television programme that played on the electoral and the TV viewing passions that had overtaken Brazil in the 1980s. Você Decide simply, and seductively, offered viewers the opportunity to 'vote' by telephone on the outcome of a dramatized social problem. By phoning in during the last commercial break, viewers were 'empowered' in lending their support, their (pre-structured) 'choice', to one of several possible and pre-produced final chapters to the day's episode. Themes dealt with included religion, ethics, rural, urban, poor, middle-class, indeed the myriad of struggles in personal choices and preferred outcomes in Brazilian society. Inexpensive pay phones were readily available, even in the slums. As sociologist Francisco Jacob Pimenta da Rocha put it in his article, "Você Decide": TV Globo's Search for a Brazilian God' (ROCHA; JACOB, 1995; Portuguese version, n.d.), the series "[...] personally gauged a popular verdict in situations in which the Brazilian ethical and moral order [was] purposely placed before plausible dilemmas in obtaining empathy, be it from a local or national public [...]" (ROCHA; JACOB, [2010-?], p. 36, trans. authors). One episode, for example, involved a priest who identified the murderer of his brother 
through the confessional. The alternative endings were posed as follows: should he break the secrecy of the confessional in denouncing his brother's murderer, one possible ending, or remain forever silent and protect the secrecy of the confessional, the other (ROCHA; JACOB, [2010-?], p. 39)? Programme themes typically dealt with eliciting choices regarding religious, ethical, and 'national cultural' values (ROCHA; JACOB, [201-?], p. 41).

In some senses, this represented an early instance in the world of philosophically and even politically interactive TV, and the concept, and this programming format (if not the decision-making 'practice'), soon overtook a vast array of TV offerings on national networks, in Brazil, in the US, and around the world. As Gouvea Neto (1997, p. 261) noted, the idea behind Você Decide "[...] was exported to 39 countries in Europe, Asia, Africa, and Latin America in 1995. The American company DLT...bought the rights for the US, Canada, Australia, and New Zealand. The Swedish version became the most popular TV show in Sweden. On average, 80,000 viewers call the company each week [...]".

This seemed in some respects to be a natural growth of the medium of TV. Marshall McLuhan long ago argued that "TV is a medium that rejects the sharp personality and favours the presentation of processes rather than products [...]" (MCLUHAN, 1964, p. 337). TV, it seems, emphasises the same sorts of sensibilities that might be called into play in assessing, for example, the suitability of a democratic candidate who had been caught up in a corruption scandal. "Você Decide", with its weekly offering of difficult ethical decisions, provided poor and middle-class Brazilians with practice voting in the public interest. In essence, the programme represented "[...] a hierarchical redefinition of the interaction between those who produced television images and those who received them [...] " (ROCHA; JACOB, [201-?], p. 38).

'Você Decide' seems to have encouraged or combined trends already in play, and already deeply embedded in Brazil's television and political cultures: it contributed, if only because of the mania and self-identification with which Brazilians already viewed novelas, to a blurring of broadcast fiction and factual reporting; it extended individual empowerment ('voting' on difficult moral issues) shortly after the advent in Brazil of mass demands for the franchise, such as Diretas Já (Rights Now!), which had mobilised millions of people to militate for the right to vote, to make those difficult decisions. Thus it may have contributed to apparent demands on the part of millions of impoverished and middle-class Brazilians that the national political drama, like the novela, achieve the best (popular) outcome, after a democratic and deliberate review of the facts.

\section{TV, politics, and Você Decide in Brazil}

It is often observed that the line between fiction and reality is blurred in popular television dramas. This has been true of all news media, of course, from the yellow journalism of the Nineteenth Century, through the era of radio, and now into the eras of TV, the Internet and the World Wide Web. Proof of this blurring is abundant, and when a third condition (after 'fiction' and 'reality'), that is, viewer interaction, is added to the TV menu, particularly as it was in Brazil, it is perhaps not surprising that the popular understanding of 'the outside world' of the 'televiewers' was further confused.

Television 'culture' in Brazil is particularly intense, with an extensive majority of Brazil's nearly 200 million people participating, and forming most of their views based upon their TV experiences. Power and Roberts noted in 1995 that the vast majority of Brazilians receive their political information from TV. Over the past three decades increasing numbers of Brazilians are taking an active part in the political system, although the society has become deeply polarized, with as many as half of all adults functionally illiterate (POWER; ROBERTS, 1995, p. 801), and many voters turning in blank or spoiled ballots. Nevertheless, the whole country can come to a complete stop with the final episode of a particularly popular novela. Demography plays an important part in this phenomenon. Up until the mid-1980s population growth in Brazil proceeded exponentially, with the continuous growth of slums perhaps the most egregious characteristic. Even following the dramatic drop in population growth beginning about 1982, demographic patterns persisted. Moreover, as a country possessed of intense, if gradually improving, income disparities, the television culture engaged in two contradictory tendencies: it was said to 'emancipate' the average Brazilian with its timely, relevant and sympathetic novelas (Globo, the ultra-conservative TV network, was the leader in this regard), while attempting to stress elite consumption patterns involving what amounted to luxury items for most Brazilians. The vast majority watched, dreamed, but simply could not afford (and apparently would never be able to afford) these items. As La Pastina, Rego and Straubhaar (2003, p. 6) noted in 2003 in a broader Latin American context,

The regional giants, Globo and [Mexico's] Televisa, had to deal with a more dynamic and diverse market in which their voices did not totally dominate the spectrum anymore. These two networks which each in their own particular way maintained a close relation to the dominant regime in Brazil and Mexico had to adapt to a democratic regime and a global economy. 
The point that Pastina, et al. missed in this analysis was that market forces ultimately played a determinant role in the democratisation not only of advertising, but TV programming. Moreover, increasingly democratic governments in Brazil after 1992 allowed the average Brazilian to imagine a future of relevant social participation. Beginning with Você Decide, however, Brazilians could visualise and vote on a pre-written and pre-filmed outcome, a 'best ending'. Gouvea Neto, in what amounted to a product pitch in a business journal, The International Executive, noted in 1997 that

Você Decide.... covers a wide array of challenging ethical questions including religion, sexuality, poverty, and racial issues. Two possible conclusions are offered to viewers, and they decide by calling in their votes for the one that will prevail. A running tally of the voting process is shown at each commercial interval. The program has proved to be a hit in Brazil with 24 million viewers watching the program every week, 38 percent of the country's viewers (GOUVEA NETO, 1997, p. 261).

The obvious contradiction between elite/regime interests and the neoliberal dictates of the 'market' were clearly at play here. In some episodes, the difficulty of the moral dilemma confronting the main protagonists required a difficult decision. Often the protagonists were poor slum dwellers, or lower-middle class workers living in cold water walk-up flats, dealing with problems of great relevance to the average viewer.

This was only one of many programmes with a similar focus at the time, although it appears to have represented a crucial opportunity and encouragement of the active participation of viewers in the homes, bars and city squares across Brazil to engage in passive, but nevertheless substantive, ethical and political decision-making. Large screens in public places often broadcast the programme, and the producers established a dialogue with the viewing public, listening to different opinions about the issues raised by the programme. Inexpensive public telephones were widely available, even in the favelas (slums). Because most of the dramaturgy in Brazil represented (and still does represent) the cultures of Rio de Janeiro and São Paulo, 'Você Decide' was staged each week in a different city, and spoke to its public about polemic and ethical issues in a way that encourage viewers to engage, to participate, to become aware of a wider, more national and regional, and certainly more diverse public opinion. 'Você Decide' lasted until 2000, and was by all accounts a major influence on TV viewers. The underlying principal of the programme, close identification with fictitious characters, and the known (if not always practiced) ability of 'democratic' voters to change their lives, was likely significant, a vicarious 'democratic' experience about things of immediate relevance to them.

Some have referred in general to the telenovela in Latin America as a kind of individual 'emancipation', bringing people closer to their day-to-day reality, celebrating subjects that were taboo in elite-driven societal mores, and recognising human foibles, if usually in a dream-like world of impossible opulence. If novelas have represented a kind of social emancipation, 'Você Decide' represented the franchise, the vote, difficult choices that the world brought to the most humble individuals by their TVs were ultimately subject to their judgment, and specific outcomes could rest on that approval. In an 'external' political world that was effectively as fictitious to most viewers as were the novelas, a creative blurring of fiction and 'reality' was inevitable.

\section{TV and Brazilian democracy, 2002-2006}

Democracy should be far more than a vote, although voting patterns do determine the ultimate shape and intensity of democracies. The systematic and pervasive alienation of voters, however, a fundamental tenet of the authoritarianism that beset Brazil for 21 years, has been likened to popular disenfranchisement. Alienation, in turn, represents a safe and relatively unthreatening tactic for elites. It is significant in this regard, then, that novelas tended to divide along regional lines, along urban/rural lines, along wealthy/poor, sexual and even racial lines. The traditional morality that is often evinced in rural and historical novelas reminds many of their relatively recent rural, impoverished and ethnically traditional past. Sexual and trans-gender themes tackle some of the most trying social changes in Brazil's recent past. Racial discrimination, long a 'hidden' Brazilian reality, is also a frequent subject of novelas. All of these are absorbed each evening during 'prime time' by viewers, many of whom sit in tiny shacks in slums, watching the world through a TV screen.

Vicarious participation seems to represent a divided existence for most Brazilians, one part of which is dreamlike and ideal. Another element is the world of dramatic choices and real down-to-earth problems. Yet another part, the high-end advertising, stresses the impotence of impoverished viewers, their inability to participate in a consumer society that flaunts the need to 'own' particular products to be 'full participants' in society, and the impotence of those who cannot buy such products. This is thought by some observers to fuel violence, crime and unrest among many. It can be argued that programmes like Você Decide represented 
a refreshing antidote, forging a link between the previous passive viewership of millions of Brazilians, and a new passive-active democratic culture, in which self-interested individuals of modest means could dream of participation in their society, and could ignore the traditional elite 'concerns', that had dominated the air waves. Allegations, actual and contrived, of political corruption and resulting scandals; charges of government inefficiency; the choices between elite candidates, and so on, were called into question while viewers stopped to vote on relevant and idealistically ethical outcomes. As democracy became increasingly unpopular in Latin America $^{2}$, programmes like 'Você Decide' ensured that democratic processes, at least, would become increasingly popular. John Keane has argued in a global context that the era of representative democracy is passing, and that a new era of 'monitory democracy', where NGOs and other pressure groups hold governments' 'feet to the fire', exercising the primary democratic impetus, is gradually emerging (KEANE, 2009). This explanation, however, is not fully satisfactory in clarifying the remarkable changes in the voting and popular preference poll outcomes in Brazil between 2002 and 2010, and particularly the drastic decline in blank and spoiled ballots in Brazil's compulsory voting system beginning in 2006 .

It is often argued that the presence of high-level political scandals is proof of the presence of a vibrant liberal democracy (LOWI, 1988, p. 10). A free press and a competitive party system, the argument continues, both uncover and prosecute scandals such that political reform is renewed. Brazil, the subject of over a decade of relentless and intense national political scandals, would appear by this standard to be a vibrant liberal democracy. If, however, there is apparently little voter response to scandals, little regard for what might be argued are the elite concerns with reputation and political principles, what is the character of the supporting 'democratic culture'? Lula's government was beset with a dense cloud of national scandals between 2002, when he narrowly won the presidency with a coalition of middle-class, intellectual and machine-dominated poor voters, and 2006, when he was swept to victory (albeit in the second round) with a new electoral base comprised largely of lower middle class and poor voters despite the scandals. What happened?

\footnotetext{
2 The UNDP report, 'Ideas and Contributions; Democracy in Latin America,' 2004 , demonstrates from a survey of 17,194 people in 18 countries in Latin America, including Brazil, that $54.7 \%$ of respondents 'would support an authoritarian government if it solved economic problems' (UNDP, 2004, p. 51).
}

\section{Resistance to the politics of scandal through the advent of subliminal democratic culture?}

The political truism that good economic times in liberal democracies attenuate the impact of political scandals appears to be overly facile, although it remains a common interpretation. However, how might the emergence of a renewed voter attention, 'subliminal democracy', turn voters' behaviour from formerly elite political concerns, such as political scandals and the instrumental use of patron-client relations and machine politics, to the desire to effectuate 'best outcomes' in resolving national dramas. The pattern of democratic change in Brazil, especially between 2002 and 2006, is indicative of such a fundamental transformation of democratic culture. The economic changes that President Fernando Henrique Cardoso, in office from 1995 to 2003, had brought to Brazil during his presidency and brief tenure as Minister of the Economy (1993-1995) included ending Brazil's 20-year inflation crisis, establishing a new currency, and raising economic expectations (and, to a lesser extent, the fortunes) of millions of Brazilians, principally through the creation of cash transfer programs. Lula emphasized the cash transfer programs that Fernando Henrique Cardoso had initiated in the 1990s, raising as many as 26 million people above the poverty line, and this, for many observers, explains Lula's dramatic transformation of his electoral base between 2002 and 2006, his unexpected re-election in 2006, as well as his unprecedented approval ratings and the subsequent election of his favoured candidate, Dilma Rousseff, in 2010.

However, the data reveal a different story. In 2004-2005, a majority of Brazilians were thought to prefer political systems other than democracy (UNDP, 2004), and Lula's approval ratings were not high. In fact, many observers predicted as late as 2005 that he would not win re-election in 2006. His striking success and high approval ratings in 2006 and beyond, then, must have an explanation in addition to that of the simplistic impact of the cash transfer programs. We argue, in this regard, that the simultaneous inculcation of democratic values during this key period created a sort of subliminal democratic culture, where adherents may not even have realized that they were democrats, relatively immune to publicity stunts, and even scandals, and were prepared to begin making reasoned and deliberate political judgments. Values developed through the electronic media, principally television, may well have reduced the vulnerability of the electorate to media-focused campaigns and even instrumental scandals. 
Given his initially shaky electoral base, Lula would seem to have been especially vulnerable to scandals, particularly among the poor and effectively disenfranchised of Brazil. It is a curious fact, however, that the divulging of many of the scandals of post-authoritarian Latin America served the interests of political elites, tended to be disclosed by intelligence agencies, civilian, military, and private, and, in Schumpeterian fashion, had far more to do with competition among the elite than with the interests of the country, not to mention the interests of poor and middle-class Brazilians. Scandals abounded in post-authoritarian Brazil, and were often effective political instruments, particularly when poor and middle-class Brazilians were often spoiling their ballots and thus refusing to sanction the political system. Three elements may be important in this interpretation: strident and manipulative presentation of scandals by elite-owned media, including presumed (but seldom realised) punitive outcomes; the concurrence of such scandals with (leftist) government rejection of elite agendas; and popular imagination, frequently expressed and practiced in interactive media (mostly television), and focused upon individual aspirations for self-realisation.

It was the very same elite-owned media, and especially Globo, that played a key role in the instrumental use of scandals to assure success in elite political competition. While political scandals are nothing new to comparative democratic government, the sheer volume and scope of national scandals in Brazil over the past two decades is staggering. Depending upon how they are 'counted', there have been dozens to hundreds of national-level corruption scandals in Brazil alone. Neo-liberalism and excessive individual gain have generally been at the forefront of these publicity magnets. Is the ubiquitous persistence of scandal-prone behaviour in Brazilian politics, juxtaposed in some cases (e.g., Lula's and Dilma's presidencies) with apparent electoral immunity of key candidates, proof positive that they simply no longer mattered in the new world of subliminal democracy'? Rather, the subjective understanding of deliberative voting of most of the electorate, their willingness to make reasoned and common sense judgments concerning everyday matters, seems to have become paramount. This was most clearly demonstrated in Lula's re-election campaign of 2006, as we can see at Table 1. His first term was plagued by some of the most profound political scandals in Brazilian history, and the leadership of his political party, the Workers'Party, was, with the exception of Lula himself, eviscerated by scandal just prior to the re-election campaign. Nevertheless, his voting bloc shifted dramatically, and his new voters had little concern with the national scandal that had overtaken him and his party.

Perhaps the most important element of that scandal, the 'Mensalão' scandal, was the degree to which it spread to all corners of the country's senior leadership. Televiewers could see the scandal, however, as a kind of novela, something that was only instrumentally tied to Lula and the PT. They could still 'vote' for a deliberative, and 'just' ending. Apparently, to them these allegations of scandalous behaviour were little more that elite machinations. The Mensalão scandal, rather, seems to have brought Lula's populist political appeal to their attention. His cause apparently came to be seen as a 'good cause', and their votes became ethical instruments. The paltry 'negatives' that had increased marginally from time-to-time were now gone, and not only was Lula re-elected with a powerful new electoral base. Dilma Rousseff, his chosen successor, was elected in 2010, in the second round of the elections, with 55.08 percent of the valid votes. Brazil's compulsory voting process, with fines and even disenfranchisement for non-voters, and a previously high rate of spoiled and blank ballots, now evinced the highest returns in history as shown at Table 2 .

By 2010, Você Decide, and its 'subliminal democratic' practice sessions, had been off the air for 10 years. The emancipatory role of novelas was in decline, Brazilians were increasingly expressing their contentment with democracy. The complex interrelation between TV fiction, TV 'reality', and the political engagement of most Brazilians, earlier evident to some extent in the non-voting patterns in Brazilian elections, had been transformed.

After 8 years of relentless and overlapping scandals involving President Lula's Workers' Party (PT), popular evaluation of the Lula presidency, and of Lula himself, showed little effect after an initial drop during the

Table 1. 2006 Presidential election.

\begin{tabular}{lcccc}
\hline \multicolumn{1}{c}{ Candidates } & Votes & \% 1st round & \multicolumn{1}{c}{ Votes } & \% 2nd round \\
\hline Lula & $46,662,365$ & $48.61 \%$ & $58,295,042$ & $60.83 \%$ \\
Alkmin & $39,968,369$ & $41.64 \%$ & $37,543,178$ & $39.17 \%$ \\
Valid Vote Totals & $\mathbf{9 5 , 9 9 6 , 7 3 3}$ & $\mathbf{1 0 0 . 0 0 \%}$ & $\mathbf{9 5 , 8 3 8 , 2 2 0}$ & $\mathbf{1 0 0 . 0 0 \%}$ \\
(Turnout=83.2\% and $\mathbf{8 1 . 0 1 \% )}$ & & & & \\
\hline
\end{tabular}

Source: Brasil (2006). 
Table 2. Abstentions, blank and null votes, brazilian presidential elections.

\begin{tabular}{|c|c|c|c|c|}
\hline Pres. Elections & $1^{\text {st }}$ Round & $1^{\text {st }}$ Round & $2^{\text {nd }}$ Round & $2^{\text {nd }}$ Round \\
\hline \multicolumn{5}{|l|}{1989 Election } \\
\hline Abstentions & & $11.8 \%$ & & $14.4 \%$ \\
\hline Blank Votes & & $1.6 \%$ & & $1.4 \%$ \\
\hline Null Votes & & $4.8 \%$ & & $4.4 \%$ \\
\hline Total & & $18.2 \%$ & & $20.2 \%$ \\
\hline \multicolumn{5}{|l|}{1994 Election } \\
\hline Abstentions & $16,843,966$ & $17.8 \%$ & No $2^{\text {nd }}$ Round & $\begin{array}{c}\text { No } 2^{\text {nd }} \text { Round in } \\
1994\end{array}$ \\
\hline Blank Votes & $7,192,116$ & $9.2 \%$ & & \\
\hline Null Votes & $7,444,017$ & $9.6 \%$ & & \\
\hline Total & $31,480,099$ & $36.6 \%$ & & \\
\hline \multicolumn{5}{|l|}{1998 Election } \\
\hline Abstentions & & $2.8 \%$ & & \\
\hline Blank Votes \& Null Votes & $15,575,298$ & $18.7 \%$ & & \\
\hline Total & & $21.5 \%$ & & \\
\hline \multicolumn{5}{|l|}{2002 Election } \\
\hline Abstentions & & $7.3 \%$ & & \\
\hline Blank Votes \& Null Votes & $9,852,985$ & $10.4 \%$ & $5,499,893$ & $6.0 \%$ \\
\hline Total & & $17.7 \%$ & & $20.5 \%$ \\
\hline \multicolumn{5}{|l|}{2006 Election } \\
\hline Abstentions & & $8.29 \%$ & & $12.96 \%$ \\
\hline Blank Votes & $2,866,191$ & $2.73 \%$ & $1,351,234$ & $1.33 \%$ \\
\hline Null Votes & $5,957,117$ & $5.68 \%$ & $4,806,998$ & $4.71 \%$ \\
\hline Total & & $16.7 \%$ & & $19.0 \%$ \\
\hline \multicolumn{5}{|l|}{2010 Election } \\
\hline Abstentions & $24,610,296$ & $18.12 \%$ & $29,197,152$ & $21.50 \%$ \\
\hline Blank Votes & $3,479,340$ & $3.13 \%$ & $2,452,597$ & $2.30 \%$ \\
\hline Null Votes & $6,124,254$ & $5.51 \%$ & $4,689,428$ & $4.40 \%$ \\
\hline Total & & & & $28.2 \%$ \\
\hline
\end{tabular}

Source: Brasil (2013).

height of the Mensalão scandal in 2005 and early 2006. In 2010, at the end of his term, Lula had an evaluation of good or excellent over $87 \%$ (BONIN, 2010).

A deeper and more penetrating question involves the waxing and waning of the popularity of democracy qua system in Brazil. By 2004, and the extensive UNDP survey on democracy in Latin America, Brazil was one of the Latin American countries in which a majority of the electorate preferred a system other than democracy. Some have speculated that the continuing inability of democracy to deliver economic well being to most Brazilians was responsible. By 2006 Lula's cash transfer programs had raised as much as 26 million people above the poverty level. Nevertheless, his widespread support in that second election, which apparently happened at the last moment, when voters had to go to the polls, and Dilma Rousseff's similar election in 2010, are related to more than a healthy economy and cash transfer programs. Voters were undeterred by allegations of corruption. They seemed to have been more concerned with making the right decisions at the voting booth, we must surmise, after decades of watching novelas, and quasi-novelas like Você Decide, and pondering what it means to make 
the right decision. They were no longer willing to spoil their ballots, or simply vote for their local machine-supported candidate.

\section{Conclusion}

It is no exaggeration to say that the flight of the rural poor in Latin America to the urban slums, the favelas of Rio de Janeiro and bairros of São Paulo, the barrios of Mexico City, is both typical of an impending world crisis, a 'planet of slums', as one observer has called it (DAVIS, 2006), and ultimately significant as regards the future of democracy. It is a process that is accelerating today and that includes the most extreme forms of poverty. In Brazil it triggered an era of populism in the $1950 \mathrm{~s}$ and $60 \mathrm{~s}$, a consequent era of military authoritarianism in the 1960s and 1970s, and a process of controlled democratisation that has evolved into the present-day vibrant democratic culture. The intense poverty of the urban slums, including a relative loss of identity, has been liberally seasoned with obsessive viewing of corporate-controlled $\mathrm{TV}$, replete with intense advertising of products and lifestyles that are virtually unobtainable, and hence the establishment of a vicarious existence for millions of people. However, the TV novela, a concession by ultra-conservative TV networks to their market, has offered a sympathetic portrayal of the problems and struggles of the common people, lower middle class and poor, and was regarded in some senses as a kind of mobilization for cultural emancipation, if not, as we argue, a vicarious economic democratisation. Você Decide, went a significant step further in offering viewers the chance to vote each week for their preferred outcome in a difficult social or even moral question. This early form of interactive TV, which was marketed internationally by Globo, its corporate TV network and originator, and copyrighted for use by telephone and computer voting on TV in the US, Canada, European, African, Asian, other Latin American and Oceania countries ${ }^{3}$, offered Brazil's rural and urban poor and lower middle classes a chance to shift, if ever so subtly, from vicarious economic democratisation, the 'emancipation' of the ever-present novelas, to a subliminal democracy, practice in voting for preferred 'best' or 'wisest' ethical outcomes. This offers a better, albeit not complete, explanation of Lula's 2006 re-election with a new electoral base.

\footnotetext{
${ }^{3}$ Broadcasters in these countries continue to pay royalties to Globo for use of their intellectual property.
}

Novelas and dramaturgies seem to have reinforced to some extent the romance of democracy, the individual empowerment and fulfilment of voting, at precisely a time when the popularity of democracy as a system was declining precipitously among Brazilians. The emancipator 'magic' of novelas has involved their blurring of the line between fact and fiction, between romance and reality. Practice in voting for preferred fictional outcomes, in these circumstances, has had a significant cultural influence vis-à-vis the practice of voting: rather than falling into the two alternatives that are normally ascribed to voting, i.e., for the public good, or for immediate personal gain ('barter politics'), interactive TV, and especially Você Decide, offered a third motive for voting: the preferred, or personally meaningful, outcome, further blurring the line between fact and fiction.

The election of Dilma Rousseff to the presidency in October, 2010, was effectively immune in this new climate of apparent 'subliminal democracy'. Dilma's election was apparently a graphic demonstration TV justice for most viewers, who had been 'schooled' on the resistance to the dictatorship with such novelas as Anos Rebeldes (Years of Revolt), a touching account of the dilemmas and suffering of young Brazilians resisting the dictatorship. Dilma had been a guerrilla (if not guerrilla leader, although this is disputed) who was accused of murder, and who was herself arrested, imprisoned and severely tortured between 1970 and 1972. Although Você Decide had been defunct for a decade in 2010, the vote for a 'good outcome' to this novela-like story, despite Dilma's limited personal popularity in the year prior to her election, seems logical in this context.

An examination of voting patterns, particularly after 2002, when Lula, not yet a 'dream candidate' of the millions of urban poor in Brazil, was first elected President, suggests the importance of this 'third motive'. Whether it was obsessive involvement with 'emancipatory' novelas, and quasi-novellas like Você Decide, or not, it is apparent that decisions by the urban poor to vote for the PT candidates (Lula in 2006, and Dilma in 2010) have remained relatively oblivious to elite appeals to the 'public good' to vote against them principally because of major corruption scandals. Voters are apparently increasingly deciding for themselves, weighing the ethical arguments, and striving to make the 'right' choice. Moreover, spoiled and blank ballots and abstentions in Brazil's compulsory voting system have stabilised and even declined. Voter alienation seems to be declining, and predicted voting patterns (e.g., the predicted defeats 
of Lula in 2006, and of Dilma in 2010, for example) were not supported by outcomes at the polls. In other words, scandals did not seem to determine voting outcomes. Cash transfer programs, the raising of as many as 26 million people above the poverty line in a relatively short period, may have had a subtle effect, although this was not apparent in early 2006. Making a choice, and making the right choice'-even in the midst of the scandal clusters and immense media coverage of them - remained of overriding importance in 2006 and 2010.

It would be a mistake to ignore the role of the obsessive TV culture in Brazil in this regard. Millions of urban poor have grown up despairing over the magical consumerism that they witness on $\mathrm{TV}$, and in which they will never share, while many others are apparently choosing, rather, to embrace elements of a democratic culture, in the spirit of the 'emancipation' and sympathy, blurring fact and fiction, in focusing upon everyday problems of ordinary people. This, we argue, harbours major political implications for Brazil, Latin America, and perhaps the world. What we have called subliminal democracy, continual practice in thinking about, and even voting on difficult moral issues, and hence strengthening individual 'emancipation', holds limitless opportunities for democracy on this 'planet of slums'.

\section{Agradecimentos}

Paulo Gustavo Pellegrino Corrêa has financial support for the research project Pró-Defesa (Call 031-2013).

\section{References}

BONIN, R. Popularidade de Lula bate recorde e chega a 87\%, diz Ibope. G1, Brasília, 16 dez. 2010. p. 1-2. Disponível em: <http:/g1.globo.com/politica/ noticia/2010/12/popularidade-de-lula-bate-recordee-chega-87-diz-ibope.html>. Acesso em: 12 nov. 2013

BRASIL. Tribunal Superior Eleitoral - TSE. Estatística das eleições 2006. Brasília, 2006. Disponível em: $<$ http://www.tse.gov.br/internet/index.html >. Acesso em: 18 dez. 2013. Brasília.

BRASIL. Tribunal Superior Eleitoral - TSE. Repositório de dados eleitorais. Brasília, 2013. Disponível em: $<$ http://www.tse.jus.br/eleicoes/estatisticas/repositoriode-dados-eleitorais $>$. Acesso em: 15 nov. 2013.

DAVIS, M. Planet of slums. London: Verso, 2006.

DEUTSCH, K. W. The nerves of government: models of political communication and control. New York: The Free Press, 1963.
FREIRE, P. Pedagogy of the oppressed. London: Penguin, 1996.

GOULD, B. The democracy sham: how globalisation devalues your vote. New Zealand: Craig Potton Publishing, 2006.

GOUVEA NETO, R. Case study: TV Globo: the brazilian media giant. The International Executive, v. 39, n. 2, p. $255-269,1997$. http://dx.doi.org/10.1002/ tie. 5060390210 .

INSTITUTO BRASILEIRO DE GEOGRAFIA E ESTATÍSTICA - IBGE. Censo Demográfico 2010: características da população e dos domicílios: resultados do universo. Rio de Janeiro: IBGE, 2011

KEANE, J. The life and death of democracy. New York: WW Norton and Company, 2009.

LA PASTINA, A. C.; REGO, C. M.; STRAUBHAAR, J. D. The centrality of telenovelas in Latin America's everyday life: past tendencies, current knowledge, and future research. Global Media Journal, v. 2, n. 2, 2003. Available from: $<\mathrm{http}$ ://lass.calumet.purdue. edu/cca/gmj/OldSiteBackup/SubmittedDocuments/ archivedpapers/Spring2003/intro_lapastina.htm>. Access in: 23 Aug. 2013.

LOWI, T. J. Forward to the politics of scandal. In: MARKOVITZ, A. S.; SILVERSTEIN, M. Power and process in liberal democracies. New York: Holmes and Meier, 1988. p. 7-12.

MCLUHAN, M. Understanding media: the extensions of man. London: Routledge, 1964.

POWER, T. J.; ROBERTS, J. T. Compulsory voting, invalid ballots, and abstention in Brazil. Political Research Quarterly, v. 48, n. 4, p. 795-826, 1995

ROCHA, P.; JACOB, F. 'Você Decide': Rede Globo à procura de um Deus brasileiro. Revista Resgate, v. 4, n. 5, p. 33-46, [201-?]. Available from: <http:// www.cmu.unicamp.br/seer/index.php/resgate/article/ download/56/61>. Access in: 24 Nov. 2012.

ROCHA, P.; JACOB, F. The decision is yours': TV Globo's search for a brazillian god. Journal of Latin American Cultural Studies, v. 4, n. 1, p. 51-63, 1995. http://dx.doi.org/10.1080/13569329509361847.

SIMPSON, A. Xuxa: the mega-marketing of gender, race and modernity. Philadelphia: Temple University Press, 1993.

UNITED NATIONS DEVELOPMENT PROGRAMME - UNDP. Democracy in Latin America: towards a citizens'democracy. New York, 2004. Report.

VINK, N. The telenovela and emancipation: a study on tv and social change in Brazil. Amsterdam: Royal Tropical Institute, 1988.

Received: 05 july, 2015 Accepted: 11 oct., 2015 